\title{
PENDIDIKAN MULTIKULTURAL DALAM DESAIN KURIKULUM DAN PEMBELAJARAN KEAGAMAAN ISLAM
}

\author{
Abdurrahmansyah \\ Program Pascasarjana UIN Palembang \\ J.. Prof. K.H. Zainal Abidin Fikri KM. 3,5 Palembang Sumatera Selatan \\ E-mail: abdurrahmansyah73@radenfatah.ac.id
}

\begin{abstract}
Multicultural Education In Curriculum Design and Islamic Religious Learning. Multicultural education is a contemporary educational paradigm that needs to be responded by Islamic educational institutions. As a religion, Islam has a very strong root of multicultural education. In the context of Indonesia, the concept of Bhinneka Tunggal Ika is a collective agreement on the values of universal unity in diversity living with the values of rahmatan lil 'alamin that need to be developed through practices and traditions of Islamic education in Indonesia. Integrative design of curriculum and learning becomes one of the important alternatives considered as an effort to instill multicultural values through the school system. The open attitude of the teachers, the availability of teaching materials, the supportive school environment, and the pattern of teacher training with multicultural insight become the supporting factors of effective implementation of multicultural education in schools and madrasah.
\end{abstract}

Keywords: multicultural education; curriculum; Islamic religious learning; integrative.

\begin{abstract}
Pendidikan Multikultural Dalam Desain Kurikulum dan Pembelajaran Keagamaan Islam. Pendidikan multikultural merupakan paradigma pendidikan kontemporer yang perlu direspon oleh institusi pendidikan Islam. Sebagai sebuah agama, Islam memiliki akar pendidikan multikultural yang sangat kuat. Dalam konteks keindonesiaan, konsep Bhinneka Tunggal lka merupakan kesepakatan bersama mengenai nilai-nilai hidup unity in diversity yang bersifat universal senapas dengan nilai-nilai rahmatan lil 'alamin yang perlu dikembangkan melalui praktik dan tradisi pendidikan Islam di Indonesia. Desain kurikulum dan pembelajaran yang bersifat integratif menjadi salah satu alternatif yang penting dipertimbangkan sebagai upaya menanamkan nilai-nilai multikultural melalui sistem persekolahan. Sikap terbuka dari para guru, ketersediaan bahan ajar, lingkungan sekolah yang mendukung, serta pola pelatihan guru yang berwawasan multikultural menjadi faktor pendukung efektifnya pelaksanaan pendidikan multikultural pada sekolah dan madrasah.
\end{abstract}

Kata kunci: pendidikan multikultural; kurikulum; pembelajaran keagamaan Islam; integratif.

\section{Pendahuluan}

Isu mengenai perbedaan agama, suku, ras, dan antar golongan banyak ditemukan sebagai pemicu ketidakharmonisan hubungan antar sesama di masyarakat. Indonesia-melebihi kebanyakan negara-negara lain-merupakan negara yang tidak saja multisuku, etnik dan agama, tetapi juga multi budaya. Kemajemukan tersebut pada satu sisi merupakan kekuatan sosial dan keragaman yang indah apabila bersinergi dan saling bekerjasama untuk embangun bangsa. Namun, pada sisi lain, kemajemukan tersebut akan menjadi pemicu dan penyulut konflik dan kekerasan yang dapat menggoyahkan sendi-sendi kehidupan berbangsa apabila tidak dikelola dan dibina dengan tepat dan baik.

Banyak peristiwa yang menunjukkan betapa dampak dari ketidak harmonisan ini terjadi di Indonesia, yang kemudian bermuara pada konflik horizontal, tidak hanya gesekan secara psikis melainkan juga secara fisik, dan menimbulkan banyak korban, baik material maupun immaterial. Maka, disinilah diskursus dan implementasi multikulturalisme menemukan tempatnya yang berarti dan tentu saja pendidikan menjadi satu faktor penting. ${ }^{1}$ Berbagai fenomena tersebut seharusnya tidak dilihat sebagai hal yang biasa,

1 Martin Van Bruinessen, "Genealogies of Islamic Radicalism in Post-Suharto Indonesia", dalam Jurnal Southeast Asia Research, Nomor. 2, 2002, h. 117. 
tetapi perlu dipandang sebagai potensi yang bisa saja memungkinkan terjadinya disintegrasi di kalangan masyarakat bangsa. Karena itu, hal ini penting dipikirkan untuk mengembangkan dialog intelektual agar realitas perbedaan justru menjadi bonus sosial untuk meningkatkan produktivitas kemanusiaan.

Salah satu dimensi yang sangat mungkin dimainkan untuk mendialogkan perbedaan menjadi kekuatan sosial adalah melalui pendidikan. Paradigma pendidikan perlu dikembangkan dan diorientasikan untuk membangun kesadaran intelektual para peserta didik untuk melihat berbagai realitas perbedaan sebagai potensi kekuatan yang harus dihargai dan justu penting dipelihara. Di sisi lain, kurikulum pendidikan dengan berbagai komponen di dalamnya (tujuan, konten, proses, dan evaluasi) harus dikembangkan dalam konteks masyarakat dengan berbagai keragaaman budaya (multiculture). Sekolah tidak boleh menjadi institusi yang justru menyemaikan dan melanggengkan pandangan sempit mengenai budaya dan realitas sosial. ${ }^{2}$

Masyarakat Indonesia secara demografi memiliki kuantitas muslim terbesar sehingga pelaksana dan pengguna jasa pendidikan di negeri ini adalah sebagian besar kaum muslim (orang Islam). Dengan demikian, penting menegaskan paradigma pendidikan Islam dan posisi mainstream pandangan keislaman mengenai keragaman dan upaya membangun kebersamaan. Signifikansi mengembangkan upaya ini karena secara substantif umat Islam sejak awal telah terorganisir pandangan teologis pendidikan mereka ke dalam berbagai kelompok kriteria. Bagi kalangan muslim konservatif pengembangan pendidikan Islam tidak perlu sampai menyentuh sisi terluar dari fenomena kemoderenan. Kalangan muslim liberal menganggap kaidah teologis kependidikan Islam

${ }^{2}$ Beberapa tokok pendidikan pembebasan seperti Paolo Freire, Ivan Illich, Erich From, dan seterusnya banyak mengkritik model persekolahan yang justru memenjarakan kebebasan sehingga keragaman justru dianggap sebagai ancaman. Sekolah di satu sisi justru menerapkan paradigma pendidikan yang "memaksa" kepada peserta didik. Lingkungan sekolah sering dikesankan menjadi area yang kurang aman bagi kebebasan peserta didik. Lihat Ivan Illich, Deschooling Society(Membebaskan Masyarakat Dari Belenggu Sekolah), Terj. Sony Keraf, (Jakarta: Obor, 1998), h. 232. Lihat juga Freire, P. Pedagogy of The Oppressed, (New York: Continuum, 1970), h. 34 setiap saat bisa saja dikonstruksi kembali sesuai tuntutan modernitas tanpa harus terkungkung oleh pandangan-pandangan lama. Kalangan moderat memilih untuk bersikap hati-hati dalam melihat arah pengembangan pendidikan Islam modern dengan memperhatikan berbagai prinsip dasar kependidikan Islam yang universal.

Bagaimanapun beragamnya pandangan kelompok Islam mengenai keragaman, setidaknya semua kaum muslim perlu menyadari dampak dari sikap anti multikultural yang menuju kondisi kontra-produktif bagi kelangsungan peradaban modern. Beberapa kajian ilmiah telah membuktikan bahwa terdapat pengaruh antara pandangan anti-multikultural seseorang dengan kecenderungan penerimaan radikalisme atas nama agama. ${ }^{3}$ Peserta didik yang sejak awal dan secara terus menerus menerima pemahaman yang kurang apresiatif terhadap keragaman dan perbedaan, maka dapat dipastikan yang bersangkutan memiliki kecenderungan pemahaman yang bernuansa radikal (penganut garis keras) dengan latar belakang ideologi dan konsep keagamaan yang dimilikinya. Dengan demikian, para peserta didik idealnya meningkatkan kesadaran mereka mengenai budaya, nilai multikultural, dan wawasan multikultural untuk menanamkan sikap toleransi dalam menghadapi perbedaan SARA yang sudah menjadi realitas kebangsaan di Indonesia, baik secara akademik maupun non-akademik. ${ }^{4}$

Fakta tersebut, semakin meyakinkan semua pihak, betapa sangat urgen dan mendesak untuk mewacanakan pandangan multikulturalisme melalui peran pendidikan Islam. Tulisan ini bertujuan untuk menganalisis akar teologis pendidikan Islam bagi pengembangan paradigma multikulturalisme di Indonesia.

${ }^{3}$ Lihat Penelitian Gina Lestari, Persepsi Mahasiswa Tentang Multikulturalisme dan Pengaruhnya Terhadap Radikalisme Atas Nama Agama: Studi deskriftif dalam Konteks Pendidikan Kewarganegaraan di Universitas Pendidikan Indonesia, Tesis, Tidak diterbitkan (Bandung: UPI, 2013), h. 87

4 Peran lembaga pendidikan dengan berbagai pola pembelajarannya mampu mempengaruhi pola pikir dan kecenderungan pemahaman keagamaannya. Pandangan fundamentalis ternyata dapat disemai melalui berbagai pola "pembelajaran" di lembaga pendidikan. Lihat misalnya penelitian Kasinyo Harto, Islam Fundamentalis di Perguruan Tinggi Umum: kasus Gerakan Keagamaan Mahasiswa Unsri Palembang, (Jakarta: Balitbang Kemenag RI, 2008), h. 56 


\section{Pendidikan Islam dan Multikulturalisme}

Islam sebagai seperangkat ajaran yang diterima dan diyakini penganutnya sebagai cara pandang kehidupan yang sempurna sebagai tata nilai yang diwahyukan Tuhan bagi pemeluknya perlu dididik dan dibelajarkan dari generasi ke generasi melalui proses pendidikan. Dari sinilah akar munculnya berbagai konsep cara mendidik menurut Islam yang dirumuskan para penganut agama Islam dalam bentuknya yang amat beragam. Terdapat berbagai cara dalam memahami Islam melalui teks suci sehingga munculnya berbagai corak penafsiran Islam dengan berbagai produk pemikirannya yang sangat kaya sampai saat ini.

Di kalangan ilmuan bidang agama Islam (ulama) bukan hal yang baru jika terdapat perbedaan dalam memahami Islam dalam berbagai konteksnya yang memang tidak sama dari sisi setting sosiologis, psikologis, historis, ideologis bahkan politis. Islam pada tataran selanjutnya justru ditampilkan dengan berbagai keunikan dan keragamannya jika dikaitkan dengan konteks budaya masing-masing komunitas penganutnya. Beberapa peneliti sejarah sosial intelektual Islam, berhasil menunjukkan bukti adanya perkembangan dari sisi tujuan, konten, proses dan metodologi pendidikan Islam. ${ }^{5}$ Kreasi bahan ajar dan metodologis banyak ditemukan dari berbagai tokoh ulama pesantren mengenai pola penyajian materi pendidikan dan cara mempelajari konten pembelajaran. ${ }^{6}$

Tradisi pendidikan Islam di Indonesia selanjutnya menerobos berbagai konstruksi budaya komunitas dalam bentuknya yang unik dan

${ }^{5}$ Dalam konteks lembaga pendidikan Islam di Indonesia misalnya Karel Stenbrink berhasil menjelaskan terdapat pergeseran dalam tradisi pendidikan Islam yang dikelompokkannya ke dalam kategori pendidikan pesantren, madrasah, dan sekolah. Lihat karel A. Stenbrink, Pesantren, Madrasah, Sekolah: Pendidikan Islam dalam Kurun Modern, (Jakarta: LP3ES, 1986), h. 280

${ }^{6}$ Untuk konteks di Pesantren Sri Bandung di Sumatera Selatan mislanya Kiai Anwar bin Kumpul menyusun cara mempelajari materi dengan menyusun kitab atau buku ajar sekaligus menawarkan metode khas agar para santri dengan cepat dapat menghapal dan menguasai isi pelajaran. Kiai Hasyim Asy'ari menyusun kaidah-kaidah pembelajaran atau etika pendidikan bagi para santri, dan begitu seterusnya. Kreasi seperti ini merupakan suatu yang biasa bagi tradisi pendidikan Islam di Indonesia sejak awal. Kreativitas ini tentu sebagai bentuk adaptasi dan penyesuaian terhadap problem dan tantangan pendidikan pada zamannya. beragam. Istilah Kaum Tuo dan Kaum Mudo di Sumatera Selatan sesungguhnya mengindikasikan adanya perbedaan konstruksi budaya dan sosial di kalangan masyarakat Islam. Namun perbedaan itu secara sosiologis tidak dianggap sebagai petaka dan melemahkan, tetapi justru memungkinkan terjadinya dialog budaya yang mencerdaskan sebagai bentuk respon terhadap perkembangan zaman dan upaya mencari solusi atas persoalan yang dihadapi di masyarakat sosial.

Harus diakui bahwa masyarakat Islam Indonesia sejak awal telah terdiri atas berbagai pandangan keagamaan yang berbeda. Lahirnya berbagai organisasi kemasyarakatan seperti NU, Muhammadiyah, Persis, Masyumi, Tarbiyah Islamiyah, dan seterusnya merupakan bukti adanya multipandangan mengenai Islam dan ajarannya dalam batas-batas tertentu. Untuk memastikan kelangsungan pemahaman keislaman pada masing masing organisasi di atas lantas mendirikan dan menyelenggarakan institusi pendidikan dengan corak dan nuansa yang khas. Dalam konteks menjaga kekhasan tradisi pendidikan ini diduga sangat tidak mungkin untuk menemukan adanya kecenderungan menanamkan spirit multipemahaman. Pendekatan doktriner dan pola pembentukan sikap menjadi sangat mudah dikenali sebagai model pembelajaran pada masingmasing kelompok keagamaan. Meskipun demikian, bukan berarti tidak ada institusi pendidikan Islam yang mengajarkan kesadaran multikultural kepada para peserta didiknya. Penelitian yang dilakukan Ahmad Taufiq Abdurrahman justru membuktikan adanya fakta di kalangan pondok pesantren dalam mengajarkan nilai-nilai multikulturalisme. ${ }^{7}$ Secara lebih mendalam perlu menelusuri gejala di lembaga pendidikan Islam mengenai isu penanaman kesadaran multikulturalisme ${ }^{8}$ ini.

7 Ahmad Taufiq Abdurrahman, "Pesantren Modern dan Pendidikan Multikulturalisme: Observasi atas Sistem Pendidikan di Pondok Pesantren Darussalam Gontor dan alAmien Prenduan",: https://vivixtopz.wordpress.com/artikelislam/pesantren-modern-dan-pendidikan-multikulturalisme/. Diaksespadatanggal 07 April 2017.

${ }^{8}$ Pendidikanmultikultural secara definitif dapat dimaknai sebagai "an education in freedom, both in the sense of freedom from ethnocentric prejudices and biases, and freedom to explore and learn from other cultures and perpectives". LihatBikhu Parekh. "What is Multiculturalism?" dalam Jurnal India Seminar, Desember 1999. Raz J.. Ethics in Public Domain: Essays in the Morality of Law and Politics,(Oxford: Clarendon 
Terdapat beberapa strategi yang mungkin dikembangkan untuk mengajarkan kesadaran multikulturalisme di lembaga pendidikan. Pertama, perlu adanya perubahan paradigma dalam menyikapi kemajemukan budaya dalam sistem pendidikan. Kedua, perlu dilakukan reorientasi visi dan misi lembaga pendidikan Islam sebagai penegak konsep Islam rahmatan lil 'alamin. Ketiga, penting melakukan rekonstruksi dan reformulasi kurikulum yang berbasis semangat menghargai keragaman serta mengembangkan sikap inklusif dan toleran terhadap kemajemukan masyarakat di sekelilingnya.

Inti dari multikulturalisme adalah kesediaan menerima kelompok lain secara sama sebagai kesatuan, tanpa memperdulikan perbedaan budaya, etnik, jender, bahasa, ataupun agama. Multikulturalisme memberikan penegasan bahwa dengan segala perbedaannya itu mereka adalah sama di dalam ruang publik. Keith Walson menegaskan bahwa:

"Multicultural education relates to education and instruction designed for the cultures of several different races in an educational system. This approach to teaching and learning is based upon consensus building, respect, and fostering cultural pluralism within racial societies. Multicultural education acknowledges and incorporates positive racial idiosyncrasies into classroom atmospheres". 9

Multikulturalisme menjadi semacam respons kebijakan baru terhadap keragaman. Multikulturalisme sebagai sebuah gerakan menuntut pengakuan (politics of recognition) terhadap semua perbedaan sebagai entitas dalam masyarakat yang harus diterima, dihargai, dilindungi serta dijamin eksisitensinya. Indonesia sebagai negara bangsa

Press, 1996), h. 17.Dengan agak detail Calarry Sada dengan mengutip tulisanSleeter dan Grant, menjelaskan bahwa pendidikan multikultural memiliki empat makna(model), yakni, (1) pengajaran tentang keragaman budaya sebuah pendekatan asimilasi kultural, (2) pengajaran tentang berbagai pendekatan dalam tata hubungan sosial, (3) pengajaran untuk memajukan pluralisme tanpa membedakan strata sosial dalam masyarakat, dan (4) pengajaran tentang refleksi keragaman untuk meningkatkan pluralisme dan kesamaan. Lihat Clarry Sada, "Multicultural Education in Kalimantan Barat: An Overview", dalam Jurnal Multicultural Education in Indonesia and South East Asia, edisi I, tahun 2004, h. 85

9 Lihat Keith Wilson, "Multicultural Education", http:// www.edchange.org/multicultural/papers/keith.html., Diakses pada tanggal 16 April 2017. (nation state) telah memiliki Pancasila sebagai dasar filosofis bangsa yang digali dari nilai-nilai luhur bangsa. Menerima Pancasila otomatis akan menerima filosofi Bhinneka Tunggal Ika (berbedabeda namun tetap satu juga). Nilai-nilai budaya bangsa Indonesia sejak awal menyadari akan eksistensi kesatuan dalam keragaman. Prinsip dasar kebangsaan ini penting dipertahankan dalam pergaulan masyarakat kontemporer, karena menegaskan pentingnya kesataraan, keadilan, keterbukaan, pengakuan perbedaan, dan toleransi yang akan berujung harmoni. Dengan demikian, sebagai sebuah gerakan budaya, multikulturalisme adalah bagian integral dalam pelbagai sistem budaya dalam masyarakat yang salah satunya dalam pendidikan, yaitu melalui pendidikan yang berwawasan multikultural.

Persoalannya adalah ternyata pemerintah sendiri tidak cukup tegas mengarahkan tujuan pengembangan multikulturaslisme melalui regulasi pendidikan.Djohar dengan sangat keras mengkritik ambiguitas pemerintah dalam upaya ini. Merujuk Undang-undang Sisdiknas Nomor 20 tahun 2003, pasal 30 misalnya regulasi pendidikan kita menggunakan istilah "Pendidikan Keagamaan" untuk menunjukkan proses pembelajaran agama di sekolah, bukan istilah "Pendidikan Agama”. Dengan demikian, di sekolah umum seharusnya tidak diajarkan agama tetapi pendidikan keagamaan. Menurut Djohar, yang menjadi tekanan pelaksanaan pendidikan keagamaan adalah etika bagaimana berprilaku hidup beragama diberlakukan di antara anak bangsa dalam hidup bermasyarakat. Tetapi kenyataannya sampai saat ini tidak terwujud, justru di sekolah umum diajarkan agama.Dalam pada itu, rumusan pasal-pasal regulasi pendidikan mengandung kontradiksi yang amat parah karena menggunakan istilah yang tidak terpelihara pemaknaannya. ${ }^{10}$

Sangat penting merumuskan konsep pembelajaran pendidikan keagamaan dalam konteks keadaan bangsa yang multikultural dan majemuk, di mana konten dari misi pendidikan keagamaan

10 Lihat Pengantar Djohar dalam buku Listia, Laode Arham, dan Lian Gogali, Problematika Pendidikan Agama di Sekolah: Hasil Penelitian Pendidikan Agama di Kota Jogjakarta 2004-2006, (Jogjakarta: Dian Interpidei, 2007), h. xiii-xvii. 
itu adalah untuk mengkaji nilai-nilai kebersamaan antara agama dan nilai-nilai kebaikan antar agama serta nilai-nilai umum antara agama. Karena itu, pendidikan keagamaan di sekolah tidak dihajatkan untuk menghasilkan peserta didik menjadi ahli agama. Memang perlu keberanian dan ketegasan untuk membangun paradigma pendidikan Islam berbasis nilai-nilai multikultural. Karena tidak semua pemeluk salah agama yang memiliki semangat kebersamaan yang baik. Dalam setiap agama selalu saja terdapat kelompok yang anti toleransi, sehingga perlu suatu "kekuatan dari dalam" untuk memutuskan menerima konsep kebersamaan melalui sebuah konsensus yang kuat. Peran tokoh agama yang mumpuni dan berwawasan luas dan bijak serta dipanuti sangat menentukan arah penguatan semangat multikulturalisme semacam ini.

Membangun multikulturalisme melalui institusi pendidikan, hendaknya para pemikir pendidikan pada semua agama perlu diajak untuk mempertimbangkan kurikulum multikultural yang ditujukan untuk mengartikulasikan sebuah hubungann antara kesatuan dan perbedaan di kalangan peserta didik. Konteks perumusan kurikulum multikultural ini tentu menjadi efektif jika dikembangkan pada konteks sekolah umum di mana para peserta didik memang datang dari berbagai latar belakang sosiokultural yang beragam dan tidak sama. Dengan demikian, pemikiran ini kurang relevan jika dikembangkan pada institusi pendidikan yang peserta didiknya bersifat homogen dan tidak beragam dari berbagai latar belakangnya.

Relevansi meletakkan isu pengembangan kurikulum multikultural pada setting perbedaan latar belakang peserta didik di sekolah umum, Henry A. Giroux menegaskan bahwa "a multicultural curriculum must be develop in public schools and institution of higher education, contexts that serve to figure relations between school, teachers, students, and the wider community"." Sekolah umum harus memiliki keinginan kuat untuk mengembangkan dialog kritis (critical dialogue) antara sekolah dengan berbagai

${ }^{11}$ Henry A. Giroux, Pedagogy and Politics of Hope: Theory, Culture, and Schooling, (USA.: HarperCollins Publisher, Inc., 1997), h. 251. budaya masyarakat itu. Penegasan terhadap peran sekolah umum, mengingat kesulitan untuk mengembangkan dan menerapkan konsep kurikulum multikultural pada sekolah khusus yang dibentuk oleh setiap agama karena memang konteks input pada lembaga pendidikan khusus ini yang sejak awal tidak beragam (homogen). Selain itu, kecenderungan setiap agama untuk memiliki sikap confidence yang kuat terhadap kebenarannya sendiri menjadi faktor penghambat pengembangan konsep multikulturalisme semacam ini.

Paradigma pendidikan Islam berbasis nilainilai multikultural untuk saat ini mutlak perlu diupayakan. Pendidikan agama Islam mesti mengedepankan nilai-nilai toleransi melalui kurikulum pendidkan dengan tujuan yang menekankan pada pemahaman dan kesadaran diri untuk rela hidup bersama dalam konteks perbedaan agama dan budaya baik secara pribadi dan kelompok.Kesadaran ini sekaligus menolak primordialisme dan ekslusifisme kelompok agama dan budaya sempit.

Melkias Antonius dalam sebuah penelitiannya berhasil menegaskan bahwa penyelenggaraan pendidikan multikultural di dunia pendidikan dapat menjadi solusi nyata bagi konflik dan disharmoni yang terjadi di masyarakat. Dengan kata lain pendidikan multikultural menjadi sarana alternatif pemecahan konflik sosial budaya. Selain sebagai sarana alternatif pemecahan konflik pendidikan multikultural juga signifikan dalam membina siswa agar mereka tidak tercabut dariakar budaya yang dimiliki sebelumnya ketika berhadapan dengan realitas sosial budaya di era globalisasi. Oleh karena itu, sebagai landasan pengembangan kurikulum pendidikan nasional dalam melaksanakan kurikulum sebagai titik tolak dalam proses belajar mengajar atau memberikan sejumlah materi dan isi pelajaran yang harus dikuasai siswa dengan ukuran atau tingkatan tertentu, maka pendidikan melalui landasan kurikulum multikultural menjadi sangat penting. Dengan demikian, pendidikan multikultural ini bisa dimasukkan secara integral dalam semua mata pelajaran.Meskipun dalam format kurikulum nasional belum menjadi suatu mata pelajaran yang mandiri (berdiri sendiri), tetapi bersifat 
integratif dengan mata pelajaran Pendidikan Kewarganegaraan dan Pendidikan Agama. ${ }^{2}$

Tawaran Antonius di atas dapat dijadikan model pengembangan pendidikan multikultural dengan mengambil subjek mata pelajaran Pendidikan Agama Islam.Tentu berbagai tawaran model dan desain pendidikan multikultural masih sangat terbuka untuk dipikirkan dan dikembangkan dengan berbagai bentuknya, termasuk melihatnya dalam perspektif pengembangan kurikulum pendidikan multikultural dalam berbagai desain organisasi kurikulum secara variatif.

\section{Desain Kurikulum dan Pembelajaran Pendidikan Agama Islam Berbasis Nilai- nilai Multikultural}

Paham multikultural layak menjadi mainstream pemahaman masyarakat Indonesia. Karena itu, multikulturalisme selanjutnya penting diturunkan menjadi konsep pendidikan multikultural, untuk kemudian dirancang kurikulum pendidikan multikultural, yang akhirnya didesain menjadi pembelajaran multikultural. Langkah-langkah pengembangan konsep pendidikan multikultural di atas secara sistematis perlu diklarifikasi dari sisi landasan filosofis, teori psikologi pendidikan yang melandasinya, konsep, dan sintaks penerapannya di kelas. Filsafat humanistik, teori pendidikan moral Korlberg, teori psikologi behavioristik sampai konstruktivistik perlu dipahami secara utuh oleh para pengembang pembelajaran pendidikan multikultural.

Konsep kurikulum pendidikan multikultural harus didekatkan pada teori-teori moral. Menurut Korlberg seperti yang dikutip Parkay menegaskan bahwa pendidikan moral berlandaskan teori psikologi moral yang mendeskripsikan perkembangan moral sebagai suatu kajian bersifat empirik. Pendidikan moral juga harus mengikuti pandangan filsafat moral. ${ }^{13}$ Fokus ini perlu diketahui para praktisi pembelajaran multikultural karena

12 Melki Antonius, "Pendidikan Multikultural dalam Pengembangan Kurikulum di Sekolah", https://aldorian0507. files.wordpress.com/2010/03/pendidikan-multikultural-artiklel. pdf.Diakses pada tanggal 10 April 2017.

${ }^{13}$ Lihat Lawrence Korlberg, "The Cognitive-Developmental Approach to Moral Education”, dalam Parkay et.al., Curriculum Planning: A Contemporary Approach, Eighth Edition, (USA.: Pearson Education Inc., 2006), h. 140. tujuan pendidikan multikultural harus mampu menyentuh sisi afeksi (affective domain) ${ }^{14}$ secara mendalam, selain aspek kognitif dan psikomotorik yang terkait dengan pengetahuan tentang konsep keragaman budaya dan keterampilan menunjukkan sikap menghargai budaya secara bermakna.

Mengacu pada pandangan James Bank ${ }^{15}$, bahwa setidaknya terdapat lima dimensi yang saling berkelindan pada pendidikan multikultural, yakni: pertama, content integrations in instructional. Mendesain pembelajaran multikultural penting mengkreasi keutuhan konten dan bahan ajar dengan mengakomadsi berbagai materi budaya secara beragam untuk kemudian diajarkan dalam bentuk pembelajaran kelas yang utuh. Kedua, the knowledge construction process in instructional. Setelah melakukan desain organisasi isi (content) pembelajaran, selanjutnya penting mengupayakan substansi materi berupa seperangkat pengetahuan yang akan ditransformasikan melalui pembelajaran kelas dengan berbagai bentuk clasroom managementnya. Ketiga, An equity paedagogy intructional. Penunjukkan kemampuan mengajar (teaching skill) oleh seorang pengajar dalam suatu orkestrasi pedagogi sebagai bentuk demontrasi kemampuan mengajar dengan nuansa mencerahkan, menyenangkan, membangun, toleran, menghargai, dan berinteraksi dengan semua peserta didik tanpa membedakan agama, suku, bahasa, budaya, dan berbagai kecenderungan kelompok dalam rangka membangun kesadaran sosial baru yang lebih produktif dalam kebersamaan. Keempat, Trainning participation in instructional. Dimensi pelibatan peserta didik dalam kegiatan kelas yang kompak dan saling mendukung tujuan pembelajaran merupakan bentuk latihan yang berguna bagi peserta didik belajar perpartisipasi dalam kelompok. Bentuk latihan partisipasi ini

${ }^{14}$ Domain afeksi menjadi menonjol pada isu pendidikan multikultural karena memang inti (core) dari pembelajaran nilai-termasuk nilai-nilai multikultural-terletak pada dua nilai moral agung (two great moral values), yakni sikap peduli (respect) dan sikap bertanggung jawab (responsibility). Lihat Thomas Lickona, Educating For Character: How Our Schools Can Teach Respect and Responsibility, (Canada: Bantam Book Publisher, 1991), h. 43.

${ }^{15}$ Banks, J.A. An Introduction to Multicultural Education. (USA: Allyn and Bacon Ltd., 1994), h. 214 
sangat penting sebagai upaya membangun kebiasaan diri setiap peserta didik untuk menjadi bagian dalam setiap kelompok dalam berbagai aktivitas. Kesadaran ini merupakan modal utama yang penting dalam menerapkan pembelajaran multikultural. Kelima, Prejudice Reduction in instructional. Dalam pembelajaran multikultural menjadi penting mengajak siswa untuk terbuka memdiskusikan dan mengklarifikasi berbagai caracara budaya yang berbeda. Hal ini berguna untuk menghilangkan prasangka buruk antar sesama. Semua peserta didik harus dipastikan berada dalam kelompok secara nyaman tanda disertai kecurigaan dan prasangka yang tidak produktif. Guru dan pengajar harus mampu menjamin keterlaksanaan semua dimensi pendidikan multikultural dalam sebuah pembelajaran.

Dimensi pembelajaran multikultural di atas perlu dipastikan unsur penerapannya untuk memastikan proses ini berjalan dengan baik. Sebab jika mengabaikan implementasi dimensi ini maka tujuan pembelajaran multikultural akan mustahil terlihat tampilannya dalam pembelajaran kelas. Paling tidak terdapat beberapa tujuan pendidikan multikultural, yakni;Pertama, Mengembangkan literasi etnis dan budaya. Kedua, membangun perkembangan personal siswa mengenai kesadaran akan keragaman budaya. Ketiga, membantu siswa melakukan klarifikasi mengenai nilai yang dianutnya sehingga memilih sikap yang berguna untuk membangun kebersamaan yang lebih produktif dan harmoni. Keempat, meningkatkan kompetensi dan kemampuan peserta didik sehingga memiliki konsistensi pengetahuan, sikap, dan keterampilan yang berorientasi pada peningkatan kualitas kebersamaan. Kelima, memiliki sikap yang kuat sebagai pribadi yang peduli terhadap persoalan bersama sehingga mampu mengidentifikasi persoalan sosial dan mencarikan solusi untuk reformasi sosial yang lebih baik. Keenam, dalam konteks keindonesiaan peserta didik harus dikuatkan wawasan kebangsaan dan penting memastikan mereka untuk menerima Pancasila, Bhinneka Tunggal Ika, dan NKRI sebagai kesepakatan bangsa untuk mengatasi dan mengantisipasi gejala perpecahan dan disintegrasi bangsa. Ketujuh, memiliki wawasan lintas budaya yang kokoh dan kesadaran sebagai warga dunia.
Kedelapan, membangun sikap untuk senang hidup bersama dalam keragaman.

Upaya mencari alternatif model dan desain pembelajaran menuju ketercapaian tujuan-tujuan umum pembelajaran multikultural di atas perlu terus menerus dipikirkan oleh para pendidikan. Mengacu pada kasus pendidikan multikultural di Amerika misalnya, seperti dipaparkan Allan C. Orstein dan Francis P. Hunkins bahwa latar belakang budaya pluralis di Amerika-sama dengan fakta multietnis di Indonesia-menjadi pendorong kuat untuk mengembangkan pendidikan multikultural yang memunculkan gerakan reformasi yang mendorong kesadaran akan hak-hak sipil. Tujuan besar pendidikan multikultural di Amerika adalah agar "many etnics groups have contributed and continue to contribute to national culture". Karena itu, akan semakin efektif jika proyek ini diperankan oleh pendidikan. Karena sesungguhnya "multicultural education is essentially an orientation to education, to curriculum and the teaching of it". Agar lebih efektif menurut Orstein dan Hunkins, konten pembelajaran multikultural (curriculum materials) perlu merancang desain isi dan teknik pembelajaran yang relevan. Beberapa orientasi penting untuk dipertimbangkan mendesain isi dan proses pembelajaran multikultural adalah (1) Introducing materials that are multiracial, multietnic, nonsexist, (2) teaching values that promote cultural diversity and individuality, (3) incorporating various cultural and etnic activities in the classroom and school-community program, (4) encouraging multiculturalism and multi dialects, and (5) emphasizing multicultural teacher education program. ${ }^{16}$

Suatu hal yang sangat penting untuk dipertimbangkan dalam mengembangkan tujuan, konten, dan proses pembelajaran multikultural di sekolah adalah melalui studi dan hasil-hasil cultural research mengenai etnics background sehingga kasus-kasus genuine sebagai fakta budaya dapat secara nyata didiskusikan pada

${ }^{16}$ Lihat penjelasan Orstein dan Hunkins mengenai isu pendidikan dan pembelajaran multikultural dalam Allan C. Orstein dan Francis P. Hunkins, Curriculum: Foundations, Principles, and Issues, Third Edition, (USA: Allyn \& Bacon Company, 1998), h. 365-368. 
kelas-kelas multikultural. Dari beberapa riset pembelajaran mengenai pendidikan multikultural, desain konten pembelajaran yang efektif untuk konteks pembelajaran di kelas biasanya dirujuk dari fakta-fakta budaya dan kasus-kasus mengenai konflik dan integrasi sosial di masyarakat. ${ }^{17}$ Konten pembelajaran ini selanjutnya perlu didesain dalam sebuah proses instruksional dengan menggunakan desain tertentu.

Dari varian desain pembelajaran yang biasa dikembangkan, terdapat satu desain yang telah terbukti efektif untuk pembelajaran multikultural, yakni Integrated Multicultural Instructional Model (IMID). ${ }^{18}$ Model pembelajaran ini terdiri atas empat sisi yang saling terhubung, yakni pertama, aspek penegasan terhadap konsep pembelajaran dari sisi proses dan langkahlangkah yang dipersiapkan pengajar. Kedua, aspek materi ajar yang mengacu pada konsep integrated curriculum. Ketiga, pengembangan classroom management sehingga peserta didik dimungkinkan untuk didorong aktif dan terlibat dalam pembelajaran secara aktif. Keempat, aspek pemilihan pendekatan, metode, strategi, dan teknik pembelajaran. Pendekatan humanistik menjadi sisi penting dalam pembelajaran ini, selain tidak boleh mengabaikan pandangansocial contructivism yang ditawarkan vygotsky.

Setting penerapan desain pembelajaran dan gaya belajar ${ }^{19}$ pendidikan multikultural sangat penting diorientasikan untuk membantu peserta didik menguasai konteks sosial mereka. Tujuan khusus pembelajaran perlu diarahkan untuk mengidentifikasi berbagai perkembangan dan tantangan perbedaan kultur dengan menghadirkan berbagai desain strategi pembelajaran serta

${ }^{17}$ Lihat Orstein dan Hunkins, Curriculum: Foundations......, h. 364 .

${ }^{18}$ Jeanne L. Higbee, Irene M. Duranczyk, Linda Buturian, "Implementing Integrated Multicultural Instructional Design in Blended Courses",http://www.uwex.edu/disted/conference/ Resource_library/proceedings/46163_2011.pdf., Diakses pada tanggal 13 April 2017.

19 Dalam konteks pendidikan multikultural gaya belajar didefinisikan sebagai "modes of organizing, analyzing, classifying, assimilating and synthesizing information about the environment that are unique to each individual". Lihat "An Integrated Approach to Multicultural Education",: http://www. asccc.org/sites/default/files/publications/Integrated_o.pdf., Diakses pada tanggal 16 April 2017. mendemontrasikan berbagai kemampuan peserta didik dalam berinteraksi dalam keragaman kultur. Semua tujuan pembelajaran itu harus tertuang dalam rencana pembelajaran (lesson plan) secara terencana. $^{20}$

Pembelajaran multikultural dalam batasan tertentu menghajatkan sebuah rekonstruksi kurikulum yang relevan untuk selanjutnya mendesain bahan ajar dan, proses, dan evaluasi pembelajaran yang sesuai dengan kebutuhan peserta didik terhadap kebutuhan pemahaman mengenai multikultural. Peran dan fungsi guru sangat menentukan keberhasilan tujuan pembelajaran ini. Bennett ${ }^{21}$ menegaskan bahwa selain guru, sistem di dalam sekolah harus terlibat secara kuat dalam membangun budaya multikultural di sekolah, yaitu: peserta didik, guru, orang tua, administrator dalam sistem sekolah tersebut. Harus dipastikan adanya suasana lingkungan belajar yang mendukung interaksi yang positif, kurikulum multikultural itu sendiri, harapan dan keinginan guru yang kuat, dukungan layanan petugas tata usaha, serta sistem pelatihan guru yang baik.

Sistem pelatihan guru bagi para pengajar pendidikan multikultural di sekolah dan madrasah di Indonesia perlu mendapat perhatian serius dari otoritas pendidikan untuk memastikan proses pendidikan multikultural di Indonesia semakin efektif. Wawasan para guru-termasuk guru Pendidikan Agama Islam-mengenai pluralisme dan keragaman budaya, agama, warna kulit, bahasa, dan golongan harus menunjukkan kemantapan yang tidak meragukan bagi peserta didik. Karena itu, pandangan dan paham keagamaan (keislaman) perlu terus menerus meneguhkan sikap kebangsaan dan keindonesiaan yang kuat. Output dan outcome dari pendidikan multikultural di Indonesia harus berupa kemampuan peserta didik memahami keragaman dan mewujudkan harmoni kepada

${ }^{20}$ Lihat"Transcript of Instructional Design and Learning Styles in a Multicultural Educational Setting", https://prezi. com/7z45ywwhevgz/instructional-design-and-learning-stylesin-a-multicultural-educational-setting/. Diakses pada tanggal 16 April 2017.

${ }^{21}$ Lihat Bennett, C., Comprehensive Multicultural Education: Theory and Practice (3rd ed.). (Massachusetts: Allen \& Bacon, 1995), h. 154 
siapapun dan di manapun mereka berada. Sekolah, keluarga, dan masyarakat harus secara sinergis mengupayakan tercapainya tujuan pendidikan multikultural secara berkelanjutan.

\section{Penutup}

Pendidikan multikultural merupakan isu penting untuk direspon oleh institusi pendidikan pada berbagai levelnya dalam rangka mengupayakan dan mewujudkan harmoni dan keindahan hidup bersama dalam keragaman budaya, latar belakang sosial, bahasa, suku, bahasa, golongan, dan seterusnya. Secara prinsip dan kaidah primer kemasyarakatan Islam, keberagaman harus dilihat sebagai rahmat Tuhan dan takdir kemanusiaan yang tidak boleh dirusak dengan paham keagamaan yang sempit dan anti sosial. Pendidikan agama Islam sebagai sarana transformasi nilai menjadi penting posisinya untuk meneguhkan paham multikultural sebagai bentuk menghargai keragaman dalam ssebuah harmoni yang produktif.

Pendidikan multikultural pada tataran lanjutannya harus dikembangkan melalui desain kurikulum pendidikan multikultural yang kemudian diimplementasikan dalam desain instruksional yang berbasis nilai-nilai multikultural. Model kurikulum dan desain pembelajaran integratif menjadi salah satu alternatif yang mungkin dikembangkan pada kelas-kelas pembelajaran multikultural. Dalam pada itu, kompetensi pengajar serta dukungan secara sistemik dari berbagai komponen pendidikan menjadi sangat penting. Karena itu, kebijakan pendidikan mengenai isu multikultural harus dipandang sebagai proyek besar yang menuntut keterlibatan banyak pihak.

\section{Pustaka Acuan}

Abdurrahman, Ahmad Taufiq, "Pesantren Modern dan Pendidikan Multikulturalisme: Observasi atas Sistem Pendidikan di Pondok Pesantren Darussalam Gontor dan al-Amien Prenduan", https://vivixtopz.wordpress.com/artikelislam/pesantren-modern-dan-pendidikanmultikulturalisme/, diakses tanggal o7 April 2017.

Antonius, Melki, "Pendidikan Multikultural dalam Pengembangan Kurikulum di Sekolah", https:// aldorian0507.files.wordpress.com/2010/03/ pendidikan-multikultural-artiklel.pdf, diakses pada tanggal 10 April 2017.

Banks, J.A, An Introduction to Multicultural Education. USA: Allyn and Bacon Ltd., 1994.

Bennett, C., Comprehensive MulticulturalEducation: Theory and Practice (3rd ed.). Massachusetts: Allen \& Bacon, 1995.

Freire, Paolo, Pedagogy of The Oppressed, New York: Continuum, 1970.

Giroux, Henry A, Pedagogy and Politics of Hope: Theory, Culture, and Schooling, USA.: HarperCollins Publisher, Inc., 1997.

Harto, Kasinyo, Islam Fundamentalis di Perguruan Tinggi Umum: Kasus Gerakan Keagamaan Mahasiswa Unsri Palembang, Jakarta: Balitbang Kemenag RI, 2008.

Ivan Illich, Deschooling Society,Membebaskan Masyarakat Dari Belenggu Sekolah, Terj. Sony Keraf, Jakarta: Obor, 1998.

Jeanne L. Higbee, Irene M. Duranczyk, Linda Buturian, "Implementing Integrated Multicultural Instructional Design in Blended Courses", http:// www.uwex.edu/disted/conference/Resource library/proceedings/46163_2011.pdf., Diakses pada tanggal 13 April 2017.

Korlberg, Lawrence, "The Cognitive-Developmental Approach to Moral Education", dalam Parkay et.al., Curriculum Planning: A Contemporary Approach, Eighth Edition, USA.: Pearson Education Inc., 2006.

Lestari, Gina, Persepsi Mahasiswa Tentang Multikulturalisme dan Pengaruhnya Terhadap Radikalisme Atas Nama Agama: Studi deskriftif dalam Konteks Pendidikan Kewarganegaraan di Universitas Pendidikan Indonesia, Tesis, Tidak diterbitkan Bandung: UPI, 2013.

Lickona, Thomas, Educating For Character: How Our Schools Can Teach Respect and Responsibility, Canada: Bantam Book Publisher, 1991.

Listia, Laode Arham, dan Lian Gogali, Problematika Pendidikan Agama di Sekolah: Hasil Penelitian Pendidikan Agama di Kota Jogjakarta 20042006, Jogjakarta: Dian Interpidei, 2007.

Martin Van Bruinessen, "Genealogies of Islamic Radicalism in Post-Suharto Indonesia", dalam Jurnal Southeast Asia Research, Nomor. 2, 2002

Orstein, Allan C. dan Francis P. Hunkins, Curriculum: Foundations, Principles, and Issues, Third Edition, (USA: Allyn \& Bacon Company, 1998. 
Parekh, Bikhu. "What is Multiculturalism?" dalam Jurnal India Seminar, Desember 1999. Raz J.. Ethics in Public Domain: Essays in the Morality of Law and Politics, Oxford: Clarendon Press, 1996.

Sada, Clarry, "Multicultural Education in Kalimantan Barat: An Overview", dalam Jurnal Multicultural Education in Indonesia and South East Asia, edisi I, tahun 2004.

Stenbrink, Karel A., Pesantren, Madrasah, Sekolah: Pendidikan Islam dalam Kurun Modern, Jakarta: LP3ES, 1986.
"Transcript of Instructional Design and Learning Styles in a Multicultural Educational Setting", https://prezi.com/7z45ywwhev9z/instructionaldesign-and-learning-styles-in-a-multiculturaleducational-setting/. Diakses pada tanggal 16 April 2017.

The Academic Senate of USA., "An Integrated Approach to Multicultural Education", http:// www.asccc.org/sites/default/files/publications/ Integrated_o.pdf., Diakses pada tanggal 16 April 2017.

Wilson,Keith , "Multicultural Education”, http:// www.edchange.org/multicultural/papers/keith. html., diakses tanggal 16 April 2017. 